\title{
SIFAT FISIS PAPAN SEMEN DARI LIMBAH KULIT BATANG SAGU
}

\section{THE PHYSICAL PROPERTIES OF CEMENT BOARD FROM THE WASTE OF SAGO CORTEX}

\author{
Rohny S. Maail \\ Jurusan Kehutanan Fakultas Pertanian Universitas Pattimura \\ Penulis korespondensi email : rohny_maail@yahoo.com
}

Disetujui : 5 Januari 2018

\begin{abstract}
This research objectives were to investigate possibility of using the waste of sago cortex (Ela sagu/Wa'a) in the manufacture of cement board and to determine the physical properties of cement board based on the comparison in proportion of materials (cement, sago, water) and catalyst calcium chloride $\left(\mathrm{CaCl}_{2}\right)$. Method were applied used completely randomesed design with tree replications in $3 \times 3 \times 3$, with total 27 samples of cement board. The results shown that the waste of sago cortex ca be applied as raw materials to manufacture of cement board and fulfill the standard of particle board (JIS A 5908, 2003). The board have dencity which is almost equal to the target of dencity, lower value in water content, water absorption and thichness swelling so that have good performance in quality and stability dimensions. The sago cortex in side of base and the catalyst $\mathrm{CaCl}_{2}$ in $6 \%$ gave high performance for all physical properties of cement board.
\end{abstract}

Key words : cement board, sago, catalyst calcium chloride, physical properties

\section{PENDAHULUAN}

Nilai ekonomis sagu bukan unggul pada potensi patinya saja namun hasil ikutan lainnya mempunyai nilai tambah sebagai bahan baku industri, dimana produk buangan (limbah) pengolahan sagu yaitu ampas sagu (Metroxylon Sp.) atau sering disebut sebagai "ela sagu" dan kulit sagu atau sering disebut " $w a$ ' $a$ " dapat dimanfaatkan sebagai bahan baku pembuatan papan komposit dalam bentuk papan semen untuk menggantikan peranan kayu, yang saat ini kebutuhannya di Indonesia diperkirakan terus mengalami peningkatan setiap tahun seiring peningkatan jumlah penduduk dan kebutuhannya dalam pembangunan. Di sisi lain kemampuan alam untuk menyediakan kayu tersebut sangatlah terbatas.
Papan semen bisa menjadi produk alternatif pengganti tripleks dan papan gypsum karena keunggulan-keunggulan yang dimilikinya. Papan semen hadir untuk mengatasi kelemahan papan gypsum yang kurang tahan terhadap air, jamur, benturan keras juga rayap dan api, atau papan triplek yang tidah ramah lingkungan karena berhubungan langsung dengan penggunaan kayu log yang turun berpengaruh terhadap kelestarian hutan. Fenomena inilah yang akhirnya melahirkan bahan material berupa papan pengganti kayu atau papan tiruan kayu yang disebut sebagai papan semen. Material papan semen ini menjadi material yang bersahabat dengan alam (karena bisa menggnakan limbah), praktis dan efektif 
dalam pemasangan, serta tidak menganggu kesehatan manusia, dan menjadi salah satu pilihan pengganti tripleks dan papan gypsum. Papan semen terbuat dari bahan dasar semen yang mempunyai kandungan serat dan partikel sehingga kuat dan tidak mudah pecah. Akan tetapi papan semen memiliki kelemahan mendasar yaitu tidak semua jenis kayu cocok digunakan sebagai bahan baku. Ini terutama disebabkan oleh keberadaan bahan ekstraktif dalam kayu yang dapat menghambat proses pengerasan semen.

Katalis atau zat aditif yang sering digunakan dalam proses pengerasan papan semen dan berfungsi sebagai akselerator antara lain adalah $\mathrm{CaCl}_{2}, \mathrm{Al}_{2}\left(\mathrm{SO}_{4}\right)_{3}, \mathrm{Na}_{2} \mathrm{SiO}_{3}$, dan lainlain. Akselerator berfungsi sebagai bahan yang dapat mempercepat penguapan air dari papan semen, sehingga proses pengerasan papan menjadi lebih cepat. Kalsium klorida $\left(\mathrm{CaCl}_{2}\right)$ merupakan katalis yang cukup baik jika digunakan dalam pengerasan papan semen yang menggunakan bahan baku partikel kayu.

Terkait dengan latar belakang di atas, maka salah satu jenis produk panil kayu adalah papan semen dengan yang dengan memanfaatkan kulit batang sagu (Metroxylon Sp.) atau di Maluku sering disebut wa'a sagu. Kulit batang sagu (Metroxylon Sp.) merupakan bahan yang potensial sebagai pengganti partikel kayu karena tersedia dalam bentuk limbah yang terbuang percuma namun bisa dimanfaatkan dalam proses pembuatan papan semen. Adapun tujuan yang ingin dicapai dalam penelitian ini adalah: (1) Mengetahui kesesuaian penggunaan limbah batang sagu sebagai bahan baku pembuatan papan semen; (2) Mengetahui sifat fisik papan semen dari limbah kulit batang sagu (Metroxylon Sp.); (3) Menentukan proporsi kulit batang sagu (Metroxylon Sp.) dan presentase katalis Kalsium Klorida $\left(\mathrm{CaCl}_{2}\right)$ terbaik dalam pembuatan papan semen. Manfaat penelitian yang diperoleh adalah Memberikan informasi tentang kemungkinan pembuatan papan semen dengan kualitas yang baik dari bahan baku limbah kulit batang sagu (Metroxylon Sp.) dengan menggunakan $\mathrm{CaCl}_{2}$ sebagai katalis (accelerator).

\section{METODE PENELITIAN}

\section{Lokasi dan Waktu Penelitian}

Penelitian ini berlangsung pada bulan Maret s/d April 2015 dan berlangsung di Labolatorium Teknologi Hasil Hutan dan Laboratorium Penggergajian Jurusan Kehutanan, Fakultas Pertanian Universitas Pattimura Ambon.

\begin{abstract}
Bahan dan Alat
Bahan yang digunakan dalam penelitian ini adalah limbah kulit batang sagu yang diambil dari Dusun Rupaitu Negeri Tulehu Kecamatan Salahutu Kabupaten Maluku Tengah, Kalsium klorida $\left(\mathrm{CaCl}_{2}\right)$ sebagai
\end{abstract}


katalisator, semen (sebagai perekat), air (sebagai media pencampuran dalam pembuatan adonan papan semen). Adapun alat yang digunakan yaitu karung, ayakan ukuran $3 \mathrm{~mm}$ dan $5 \mathrm{~mm}$, ember, timbangan elektrik, flacker, oven, plastik, desikator, wadah plastik, cetakan, alat kempa dengan cold press, alat tulis, kamera, dan sarung tangan plastik.

\section{Prosedur Penelitian}

\section{Pembuatan papan semen}

Ukuran papan semen yang akan dibuat yaitu ukuran $30 \mathrm{~cm}$ x $30 \mathrm{~cm}$ x 1,2 cm (p x 1 x t) dengan sasaran kerapatan $1,2 \mathrm{gr} / \mathrm{cm}^{3}$. Proses pembuatan papan semen sebagai berikut :

\section{a. Persiapan bahan}

Bahan baku kulit batang sagu (wa'a) dimasukkan ke flacker untuk dibuat menjadi partikel. Selanjutnya dikeringkan lalu dipisahkan dengan ayakan ukuran $3 \mathrm{~mm}$ dan 5 $\mathrm{mm}$ antara serbuk, partikel dan serat dari limbah kulit batang sagu.

b. Pembuatan papan semen ;

1) Penyiapan bahan, bahan kulit batang sagu dipisahkan antara serbuk, partikel dan serat menggunakan ayakan ukuran $5 \mathrm{~mm}$ dan 3 mm. Bahan baku yang diambil adalah partikel ukuran $5 \mathrm{~mm}$ (tertahan pada sringan $3 \mathrm{~mm}$ ).

2) Pencampuran yaitu antara katalis, kulit batang sagu, semen dan air dengan proporsi bahan : 2.5 (semen) : 1 (Wa'a) : 1,25 (air)

3) Pembuatan lembaran di atas plat besi berukuran $40 \mathrm{~cm}$ x $40 \mathrm{~cm}$ x $1,2 \mathrm{~cm}$.

4) Pengepresan dengan mesin press pada tekanan 36 kgf.

5) Pengkleman untuk pengerasan awal (setting).

6) Pengerasan lanjutan (curing) selama 2 minggu.

7) Setelah tahap pengerasan selesai, dilanjutkan dengan pengeringan didalam oven (suhu $80^{\circ} \mathrm{C}$ selama $10 \mathrm{jam}$ )

8) Pengkondisian dengan suhu ruangan $26^{\circ} \mathrm{C}$ selama 2 minggu.

9) Pemotongan contoh uji dan pengujian. Pengujian dilakukan terhadap sifat fisis papan, yaitu kadar air, kerapatan, pengembangan linear, tebal dan daya serap air

Pembuatan papan semen dari wa'a sagu secara skematis yaitu sebagai berikut :

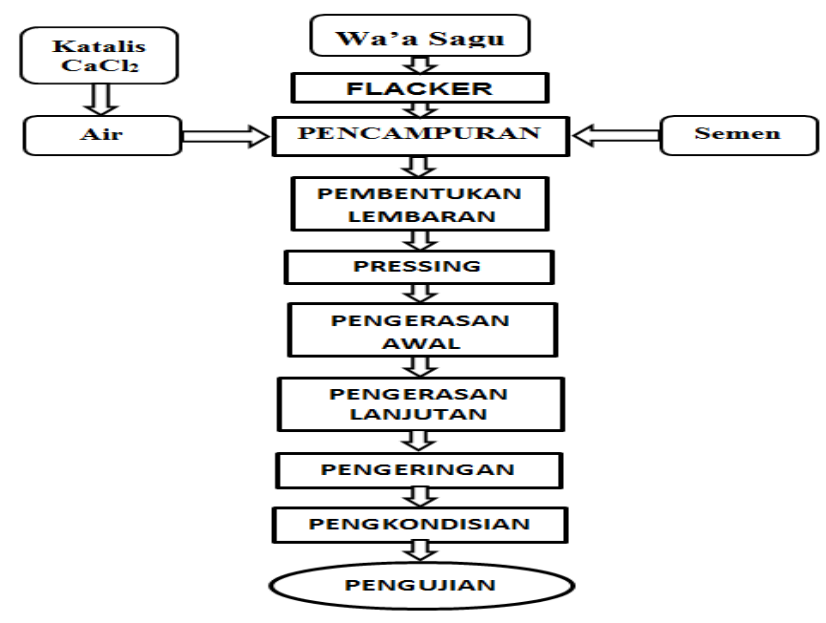




\section{Pengujian Papan Semen}

\section{Gambar 1. Proses Pembuatan Papan Semen dari Wa'a Sagu}

a. Penyiapan Contoh Uji

Setelah papan semen mendapat perlakuan pengkondisian kemudian di potong untuk dilakukan pengujian sifat fisis,yaitu antara lain : kadar air, kerapatan, pengembangan tebal dan daya serap air.

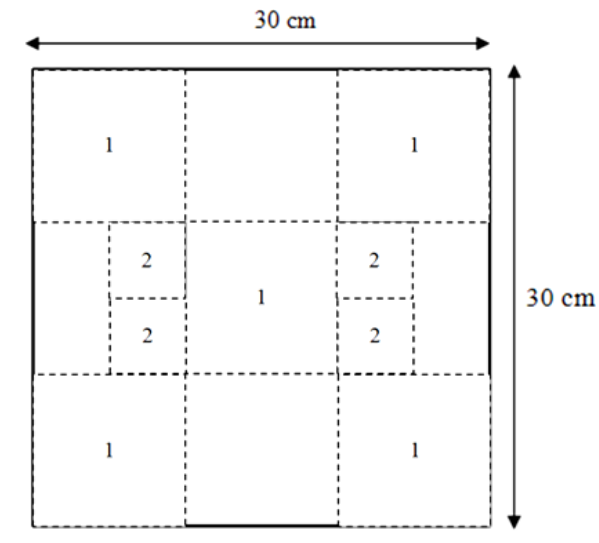

\section{Gambar 2. Pola Pemotongan Contoh Uji Menurut JIS A-5908 (1994)}

Keterangan :

1. Contoh uji kerapatan dan kadar air berukuran $10 \mathrm{~cm} \times 10 \mathrm{~cm}$

2. Contoh uji pengembangan tebal dan daya serap air berukuran $5 \mathrm{~cm} \times 5 \mathrm{~cm}$.

b. Pengujian papan semen

Sifat fisis papan semen, yaitu :

1) Kerapatan

Contoh uji berukuran $10 \mathrm{~cm}$ x $10 \mathrm{~cm}$ dalam

keadan kering udara ditimbang beratnya,

lalu diukur rata-rata panjang, lebar, dan

tebal untuk menentukan volume. Kerapatan

papan semen dihitung dengan

menggunakan rumus :

Kerapatan $=\frac{\text { Berat }(\mathrm{gr})}{\text { Volume }\left(\mathrm{cm}^{3}\right)}$

2) Kadar Air

Contoh uji berukuran $10 \mathrm{~cm}$ x $10 \mathrm{~cm}$ ditimbang untuk mendapatkan berat awal (BA), kemudian di oven dengan suhu 103 $\pm 2^{\circ} \mathrm{C}$ selama 24 jam sampai beratnya konstan (BKO). Nilai kadar air di hitung dengan rumus :

Kadar air $=\frac{\mathrm{BA}-\mathrm{BKO}}{\mathrm{BKO}} \times 100 \%$

Keterangan :

$\mathrm{BA}=$ Berat awal (gr)

$\mathrm{BKO}=$ Berat kering oven $(\mathrm{gr})$

3) Pengembangan Tebal

Contoh uji berukuran $5 \mathrm{~cm}$ x $5 \mathrm{~cm}$ x 1,2 cm diukur dimensinya pada kondisi kering udara. Dimensi tebal diukur pada pertengahan garis pada pusat diagonal contoh uji $\left(\mathrm{T}_{1}\right)$. Selanjutnya contoh uji direndam dalam air dingin selama 2 dan 24 jam, kemudian diukur kembali tebalnya $\left(T_{2}\right)$. Nilai pengembangan tebal dapat dihitung dengan rumus : 
Pengembang an tebal $=\frac{\mathrm{T}_{2}-\mathrm{T}_{1}}{\mathrm{~T}_{1}} \times 100 \%$

Keterangan :

4) Daya serap air

Pengujian daya serap air dilakukan bersamaan dengan pengujian pengembangan tebal. Contoh uji ditimbang berat awalnya sebelum perendaman $\left(B_{1}\right)$ kemudian direndam dalam air selama 2 jam dan 24 jam, kemudian contoh uji ditimbang

\section{Rancangan Percobaan}

Rancangan percobaan yang dilakukan adalah Rancangan Acak Lengkap (RAL) dengan tiga kali ulangan yaitu $3 \times 3 \times 3=27$ papan semen dengan 2 faktor yang dianalisa adalah sebagai berikut :

- Faktor A (posisi kulit batang) terdiri dari:
$\mathrm{T}_{1}=$ Tebal awal $(\mathrm{cm})$

$\mathrm{T}_{2}=$ Tebal setelah perendaman 2 jam dan 24 jam $(\mathrm{cm})$

kembali $\left(\mathrm{B}_{2}\right)$. Nilai daya serap dapat dihitung dengan rumus :

$$
\text { Daya serap air }=\frac{\mathrm{B}_{2}-\mathrm{B}_{1}}{\mathrm{~B}_{1}} \times 100 \%
$$

Keterangan :

$\mathrm{B}_{1}=$ berat contoh uji sebelum perendman (gr)

$\mathrm{B}_{2}=$ berat contoh uji setelah perendaman (gr)

$$
\begin{array}{ll}
\text { a1 } & =\text { Pangkal } \\
\text { a2 } & =\text { Tengah } \\
\text { a3 } & =\text { Ujung }
\end{array}
$$

- Faktor B (persentase Katalis $\mathrm{CaCl}_{2}$ ) terdiri dari :

\begin{tabular}{|c|c|c|c|c|c|}
\hline \multicolumn{2}{|c|}{ Faktor } & \multicolumn{3}{|c|}{ Ulangan } & \multirow{2}{*}{ Total } \\
\hline $\mathbf{A}$ & B & 1 & 2 & 3 & \\
\hline \multirow{3}{*}{ a1 } & $b_{1}$ & $a_{1} b_{11}$ & $a_{1} b_{12}$ & $a_{1} b_{13}$ & $a_{1} b_{1}$ \\
\hline & $b_{2}$ & $a_{1} b_{21}$ & $a_{1} b_{22}$ & $a_{1} b_{23}$ & $a_{1} b_{2}$ \\
\hline & $b_{3}$ & $a_{1} b_{3_{1}}$ & $a_{1} b_{32}$ & $a_{1} b_{33}$ & $a_{1} b_{3 .}$ \\
\hline \multicolumn{2}{|c|}{ Sub Total } & $a_{1} b_{.1}$ & $a_{1} b_{.2}$ & $a_{1} b_{.3}$ & $a_{1} b$. \\
\hline \multirow{3}{*}{$\mathrm{a} 2$} & $b_{1}$ & $a_{2} b_{11}$ & $a_{2} b_{12}$ & $a_{2} \quad b_{13}$ & $a_{2} b_{1 .}$ \\
\hline & $b_{2}$ & $a_{2} b_{21}$ & $a_{2} \quad b_{22}$ & $a_{2} b_{23}$ & $a_{2} b_{2}$ \\
\hline & $b_{3}$ & $a_{3} b_{31}$ & $a_{2} b_{32}$ & $a_{3} b_{33}$ & $a_{2} b_{3}$. \\
\hline \multicolumn{2}{|c|}{ Sub Total } & $a_{2} b_{.1}$ & $a_{2} b_{.2}$ & $a_{2} b_{.3}$ & $a_{2} b$ \\
\hline \multirow{3}{*}{ a3 } & $b_{1}$ & $a_{3} b_{11}$ & $a_{3} b_{12}$ & $a_{3} b_{13}$ & $a_{3} b_{1 .}$ \\
\hline & $b_{2}$ & $a_{3} b_{21}$ & $a_{3} b_{22}$ & $a_{3} b_{23}$ & $a_{3} b_{2}$ \\
\hline & $b_{3}$ & $a_{3} b_{31}$ & $a_{3} b_{32}$ & $a_{3} b_{33}$ & $a_{3} b_{3}$ \\
\hline \multicolumn{2}{|c|}{ Sub Total } & $a_{3} b_{.1}$ & $a_{3} b_{.2}$ & $a_{3} b_{.3}$ & $a_{3} b$. \\
\hline \multicolumn{2}{|c|}{ Total } & $a . b .1$ & $a . b .2$ & $a . b \cdot 3$ & $a . b$. \\
\hline
\end{tabular}

$$
\begin{array}{ll}
\text { b1 } & =\text { Katalis } \mathrm{CaCl}_{2} \text { sebanyak } 2 \% \\
\text { b2 } & =\text { Katalis } \mathrm{CaCl}_{2} \text { sebanyak } 4 \% \\
\text { b3 } & =\text { Katalis } \mathrm{CaCl}_{2} \text { sebanyak } 6 \%
\end{array}
$$

Tata letak rancangan percobaan dapat dilihat pada Tabel 2 berikut ini.

Tabel 2. Tata letak Rancangan Percobaan

Model matematis rancangan percobaan adalah :

$$
Y_{i j k}=\mu+\alpha_{i}+\beta_{j}+(\alpha \beta)_{i j}+\epsilon_{i j k}
$$

Dimana :

$\mathrm{Y}_{\mathrm{ijk}}=$ Nilai pengamatan hasil percobaan

$\mu \quad=$ Nilai tengah umum

$\alpha_{\mathrm{i}} \quad=$ Pengaruh faktor $\mathrm{A}$ (posisi kulit batang)

$\beta_{\mathrm{j}} \quad=$ Pengaruh faktor $\mathrm{B}$ (katalis $\mathrm{CaCl}_{2}$ ) 
$\alpha \beta_{\mathrm{ij}}=$ Interaksi faktor $\mathrm{A}$ dan faktor $\mathrm{B}$

$\epsilon_{\mathrm{ijk}} \quad=$ Galat percobaan

Faktor Koreksi (FK)

$=(a . b .)^{2} / \mathrm{abr}$

Jumlah Kuadrat Total ( $\left.\mathrm{JK}_{\text {tot }}\right)$

$=\sum\left(a_{\mathrm{ijk}}\right)^{2}-\mathrm{FK}$

Jumlah Kuadrat perlakuan (JKP)

$=\sum\left(a_{\mathrm{i}} b_{\mathrm{j}}\right)^{2} / r-\mathrm{FK}$

Jumlah Kuadrat jenis posisi kulit batang $\left(\mathrm{JK}_{\mathrm{A}}\right)=\sum\left(a_{\mathrm{i}} b . .\right)^{2} / b r-\mathrm{FK}$

Kuadrat Jenis presentasi katalis $\mathrm{CaCl}_{2}\left(\mathrm{JK}_{\mathrm{B}}\right)=\sum(a . b j .)^{2} / a r-\mathrm{FK}$

Interaksi Faktor A dan Faktor B

$=\sum\left(a_{\mathrm{i}} \cdot b_{\mathrm{j}}\right)^{2} / r-\mathrm{FK}-\mathrm{JK}_{\mathrm{A}}-\mathrm{JK}_{\mathrm{B}} / \mathrm{JKP}$

Jumlah Kuadarat Galat $\left(\mathrm{JK}_{\text {galat }}\right)$

$=\mathrm{JK}_{\text {tot }}-\mathrm{JK}_{\mathrm{A}}-\mathrm{JK}_{\mathrm{B}}-\mathrm{JK}_{\mathrm{AB}}$

Tabel.3 Analisa Keragaman

\begin{tabular}{lcccc}
\hline Analisa Keragaman & Db & JK & JKT & F Hitung \\
\hline $\begin{array}{l}\text { Proporsi papan } \\
\text { Semen (A) }\end{array}$ & $(\mathrm{a}-1)$ & $\mathrm{JK}_{\mathrm{A}}$ & $\mathrm{JK}_{\mathrm{A}} / \mathrm{db}_{\mathrm{A}}$ & $\mathrm{KT}_{\mathrm{A}} / \mathrm{KT}_{\text {galat }}$ \\
Presentase Katalis & $(\mathrm{b}-1)$ & & & \\
(B) & $(\mathrm{a}-1) .(\mathrm{b}-1)$ & $\mathrm{JK}_{\mathrm{B}}$ & $\mathrm{JK}_{\mathrm{B}} / \mathrm{db}_{\mathrm{B}}$ & $\mathrm{KT}_{\mathrm{B}} / \mathrm{KT}_{\text {galat }}$ \\
A x B & $\mathrm{ab}(\mathrm{r}-1)$ & $\mathrm{JK}_{\text {galat }}$ & $\mathrm{JK}_{\mathrm{AB}} / \mathrm{db}_{\mathrm{AB}}$ & $\mathrm{KT}_{\mathrm{AB}} / \mathrm{KT}_{\text {galat }}$ \\
Galat & $\mathrm{abr}-1$ & $\mathrm{JK}_{\text {total }}$ & & \\
Total & & & & \\
\hline
\end{tabular}

Jika perlakuan A dan B nyata, maka

nilai rata-rata tiap faktor dimana terdapat dilanjutkan dengan uji beda nyata jujur (BNJ) untuk melihat perbedaan antara tingkat faktor. perbedaan yang jika selisihnya lebih besar dari nilai $\mathrm{W}$, dengan rumus sebagai berikut :

Hal ini dilakukan dengan membandingkan

$W=q a($ Pidb galat $) \cdot \sqrt{\frac{K T A}{r}}$

Dimana :

$\mathrm{W}=$ Nilai BNJ

$\mathrm{P}=$ Nilai perlakuan

$\mathrm{r} \quad=$ Jumlah ulangan

$\mathrm{KT}_{\mathrm{G}}=$ Kuadrat tengah galat

\section{HASIL DAN PEMBAHASAN}

\section{Kerapatan}

Berdasarkan hasil pengujian, nilai kerapatan papan yang di hasilkan berkisar dari $1,19-1,26 \mathrm{gr} / \mathrm{cm}^{3}$. Hasil pengukuran rata-rata kerepatan papan pada berbagai taraf perlakuan selengkapnya dapat disajikan pada Tabel 4 dan histogram perbandingan kerapatan untuk setiap jenis papan semen dapat dilihat pada Gambar 3. 
Tabel 4. Rata-rata Kerapatan Papan Semen

\begin{tabular}{cc} 
Tipe papan semen & Rata-rata kerapatan $\left(\mathrm{g} / \mathrm{cm}^{3}\right)$ \\
\hline A1 B1 & 1,21 \\
A1 B2 & 1,23 \\
A1 B3 & 1,26 \\
A2 B1 & 1,20 \\
A2 B2 & 1,22 \\
A2 B3 & 1,21 \\
A3 B1 & 1,19 \\
A3 B2 & 1,20 \\
A3 B3 & 1,21 \\
\hline
\end{tabular}

Keterangan :

A1B1 : kulit dibagian pangkal, $\mathrm{CaCl}_{2} 2 \%$

A1B2 : kulit dibagian pangkal, $\mathrm{CaCl}_{2} 4 \%$

A1B3 : kulit dibagian pangkal, $\mathrm{CaCl}_{2} 6 \%$

A2B1 : kulit dibagian tengah, $\mathrm{CaCl}_{2} 2 \%$

A2B2 : kulit dibagian tengah, $\mathrm{CaCl}_{2} 4 \%$
A2B3 : kulit dibagian tengah, $\mathrm{CaCl}_{2} 6 \%$ A3B1 : kulit dibagian ujung, $\mathrm{CaCl}_{2} 2 \%$ A3B2 : kulit dibagian ujung, $\mathrm{CaCl}_{2} 4 \%$ A3B3 : kulit dibagian ujung, $\mathrm{CaCl}_{2} 6 \%$

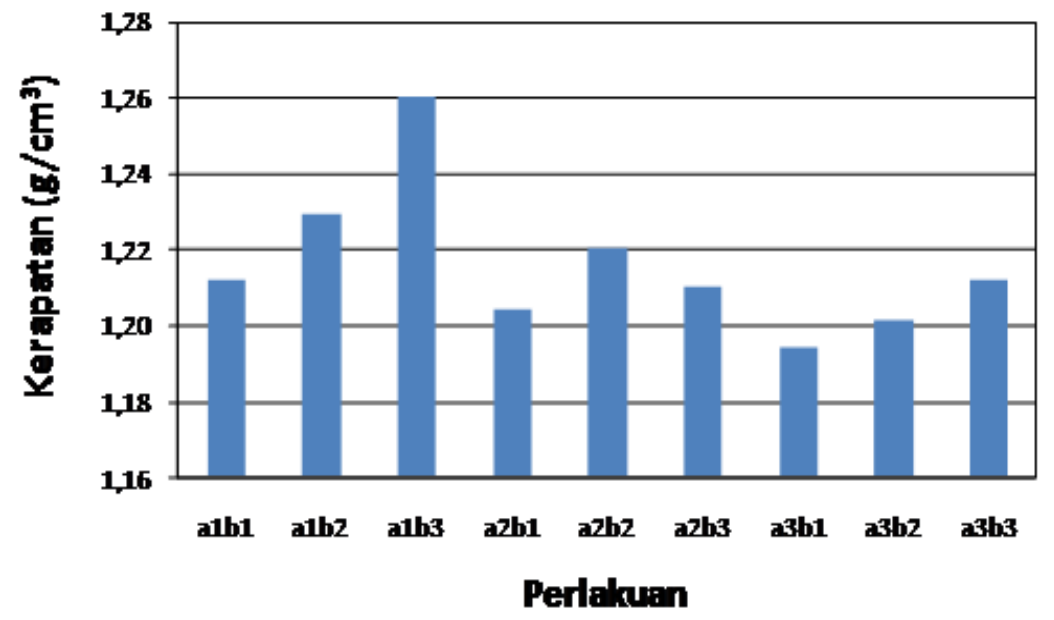

Gambar 3. Histogram Kerapatan Papan Semen

Kerapatan menunjukan banyaknya masa persatuan volume (Haygreen dan Bowyer, 1996). Sifat-sifat papan semen yang dihasilkan juga akan sangat di pengaruhi oleh kerapatan karena bisa menggambarkan sejauh mana ketahanan atau kestabilan dimensi papan dan kekuatan papan itu sendiri dalam menanggung beban serta menjadi dasar pertimbangan penggunaan produk papan semen tersebut.

Histogram pada Gambar 3 di atas menyajikan bahwa nilai rata-rata kerapatan papan semen tertinggi yaitu sebesar 1,26 $\mathrm{gr} / \mathrm{cm}^{3}$ didapat pada papan A1B3 (papan yang terbuat dari kulit sagu pada posisi pangkal dengan katalis $\mathrm{CaCl}_{2} 6 \%$ ) , sedangkan kerapatan papan semen terendah yaitu 1,19 $\mathrm{gr} / \mathrm{cm}^{3}$ terdapat pada papan A3B1 (papan yang terbuat dari kulit sagu pada posisi ujung dengan katalis $\mathrm{CaCl}_{2} 2 \%$ ).

Dalam proses pembuatan papan semen yang terbuat dari kulit batang sagu ini menunjukan bahwa walaupun proporsi bahan pembuatan papan itu sama untuk setiap perlakuan dan ulangan yaitu; 3 (semen) : 1 (kulit sagu) : 1,5 (air), namun berat bahan yang digunakan sebagai hasil perhitungan berat untuk mencapai kerapatan sasaran $1,2 \mathrm{gr} / \mathrm{cm}^{3}$, mengakibatkan kebutuhan berat masing- 
masing bahan berbeda, teristimewa berat kulit batang sagu yang digunakan apalagi papan dibuat dalam ukuran volume yang sama yaitu $30 \mathrm{~cm} \times 30 \mathrm{~cm} \times 1,2 \mathrm{~cm}$, sehingga dalam penelitian untuk mencapai sarasan ukuran volume dengan sasaran kerapatan yang sama, maka berat dari kulit batang sagu pada posisi pangkal perlu ada penambahan dengan menambahkan sejumlah partikel.

Adanya perbedaan dari nilai kerapatan ini juga disebabkan oleh perbedaan ketebalan papan yang diakibatkan pemasangan klem yang tidak merata. Meskipun untuk mencapai ketebalan sasaran sebesar $1,2 \mathrm{~cm}$ atau untuk mencapai keseragaman tebal papan telah digunakaan stick baja setebal $1,2 \mathrm{~cm}$ dalam proses pengempaan, namun adanya efek pengembangan kembali (springback) saat pelepasan plat press / kempa selama pengkondisian, maka sebagian papan mengalami pengembangan ketebalan setelah tekanan kempa dihilangkan dan penebalan selama pengkondisian.

Tabel 5.Analisis Sidik Ragam Untuk Kerapatan

\begin{tabular}{lcccccc}
\hline & & & & \multicolumn{2}{c}{ F. Tebel } \\
Sumber Keragaman & Db & JK & JKT & F.hitung & $\mathbf{0 , 0 1}$ & $\mathbf{0 , 0 5}$ \\
\hline Posisi kulit batang (A) & 2 & 0,005 & 0,00228 & $7,36^{* *}$ & 4,07 & 2,97 \\
Katalis $\mathrm{CaCl}_{2}$ (B) & 2 & 0,0002 & 0,000085 & $0,27^{\text {th }}$ & 4,07 & 2,97 \\
$\mathrm{AB}$ & 4 & 0,004 & 0,001 & $3,21^{\text {th }}$ & 5,09 & 4,00 \\
Galat & 18 & 0,006 & 0,0003 & & \\
Total & 26 & 0,014 & & & \\
\hline Keterangan : ** sangat nyata, tn $=$ tidak nyata
\end{tabular}

Data pada Tabel 5 menunjukan bahwa posisi kulit batang sagu yang digunakan dalam proses pembuatan papan semen (faktor A) berpengaruh sangat nyata, sedangkan persentasi katalis $\mathrm{CaCl}_{2}$ yang digunakan (faktor B) dan interaksi dari kedua faktor (faktor $\mathrm{AB}$ ) tidak berpengaruh nyata pada kerapatan papan semen.

Berdasarkan hasil perhitungan BNJ (Lampiran 1) terhadap Faktor A (posisi kulit batang sagu) yang berbeda sangat nyata, nilai faktor A terlihat bahwa A1terhadap A2 dan A1 terhadap A3 berpengaruh nyata terhadap kerapatan papan, sedangkan A2 terhadap A3 menunjukan perbedaan yang tidak nyata terhadap kerapatan papan.

Hal ini berarti kerapatan papan semen yang dihasilkan sangat dipengaruhi oleh posisi kulit batang sagu. Posisi kulit batang sagu bagian pangkal mempunyai kerapatan bahan yang lebih besar sehingga cukup mempengaruhi terhadap kerapatan papan, disamping dengan penambahan persentase $6 \%$ dari $\mathrm{CaCl}_{2}$ yang turut menunjang ikatan antara partikel-partikel kulit batang sagu menjadi lebih kompak dengan semen sebagai bahan pengikat.

Simatupang (1974), menyatakan bahwa sifat-sifat papan semen partikel yang dihasilkan oleh beberapa faktor, diantaranya adalah material yang digunakan (bahan baku dan teknis pengerjaan sewaktu percampuran bahan baku dan prose pengempaan serta penambahan akselator atau katalis. Hal yang sama ditegaskan oleh Moeslemi (1994), bahwa 
papan semen yang terbuat dari bahan material dengan BJ atau kerapatan yang lebih tinggi, mempunyai kerapatan papan dan berat yang lebih tinggi daripada papan yang terbuat dari bahan yang mempunyai BJ atau kerapatan yang rendah. Bila dibandingkan dengan standar JIS A 5908 (2003), yang mensyaratkan kerapatan papan maksimal 1,2 $\mathrm{gr} / \mathrm{cm}^{3}$ maka sebagian besar papan semen yang dibuat memenuhi standar tersebut terutama pada papan semen yang menggunakan persentase lebih besar $(6 \%)$.

\section{Kadar Air}

Kadar air merupakan salah satu sifat fisik papan semen yang menunjukan kandungan air papan semen dalam keadaan kesetimbangan dengan lingkungan sekitarnya. Kondisi papan yang mempunyai kadar air atau kandungan air yang berlebihan akan berpengaruh terhadap sifat fisik maupun mekanis papan tersebut. Berdasarkan hasil perhitungan kadar air papan semen pada berbagai taraf perlakuan seperti yang disajikan pada Lampiran 5, kadar air papan semen yang dibuat dari kulit batang sagu ini berkisar antara $7,67 \%-8,02 \%$ nilai kadar air papan pada berbagai taraf dapat dilihat pada Tabel 6, sedangkan histogram nilai kadar air papan untuk setiap jenis perlakuan disajikan pada Gambar 4.

Tabel 6. Rata-Rata Kadar Air Papan (\%) Pada Berbagai Perlakuan

\begin{tabular}{lc}
\hline Tipe papan semen & Rata-rata Kadar Air (\%) \\
\hline A1 B1 & 7,87 \\
A1 B2 & 7,82 \\
A1 B3 & 7,67 \\
A2 B1 & 7,76 \\
A2 B2 & 7,89 \\
A2 B3 & 7,90 \\
A3 B1 & 8,02 \\
A3 B2 & 7,96 \\
A3 B3 & 7,92 \\
\hline
\end{tabular}

Keterangan :

A1B1 : kulit dibagian pangkal, $\mathrm{CaCl}_{2} 2 \%$

A1B2 : kulit dibagian pangkal, $\mathrm{CaCl}_{2} 4 \%$

A1B3 : kulit dibagian pangkal, $\mathrm{CaCl}_{2} 6 \%$

A2B1 : kulit dibagian tengah, $\mathrm{CaCl}_{2} 2 \%$

A2B2 : kulit dibagian tengah, $\mathrm{CaCl}_{2} 4 \%$

Histogram pada gambar 4 menunjukan bahwa kadar air tertinggi setelah proses pengerasan selama 2 minggu yaitu $8,02 \%$ (A3B1) didapat pada papan semen yang terbuat dari kulit batang sagu pada posisi ujung dengan menggunakan katalis $\mathrm{CaCl}_{2} 2 \%$,
A2B3 : kulit dibagian tengah, $\mathrm{CaCl}_{2} 6 \%$

A3B1 : kulit dibagian ujung, $\mathrm{CaCl}_{2} 2 \%$

A3B2 : kulit dibagian ujung, $\mathrm{CaCl}_{2} 4 \%$

A3B3 : kulit dibagian ujung, $\mathrm{CaCl}_{2} 6 \%$

sedangkan nilai kadar air terendah yaitu 7,67\% (A1B1) didapat pada papan semen yang terbuat dari kulit batang sagu pada posisi pangkal dengan menggunakan katalis $\mathrm{CaCl}_{2}$ $6 \%$. 


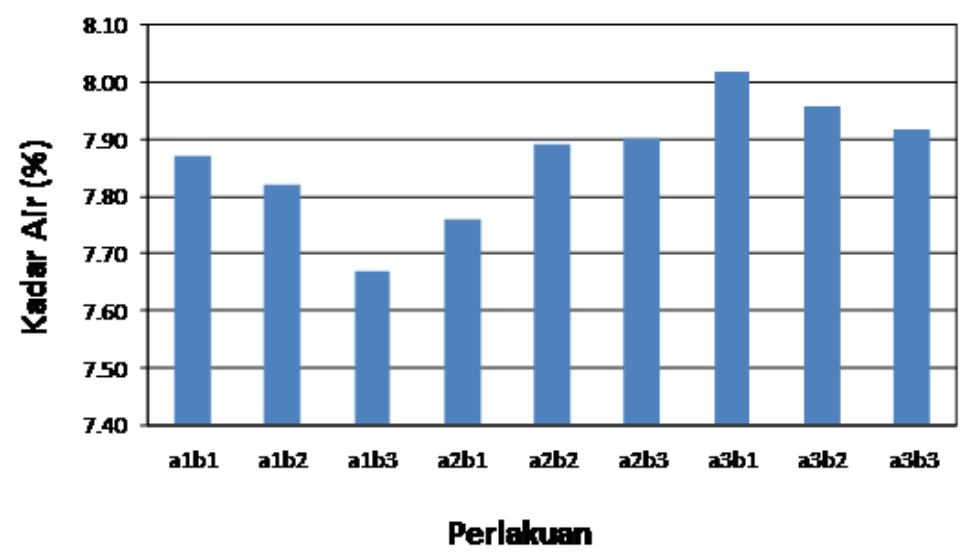

Gambar 4. Histogram Kadar Air Papan Semen

Hasil analisis ragam seperti yang terlihat pada Tabel 7 menunjukan bahwa posisi kulit batang sagu berpengaruh sangat nyata terhadap kadar air papan dimana F-hitung masingmasing perlakuan lebih kecil dari F-tabel pada taraf 5\%. Sementara Katalis dan interaksi kedua faktor tidak berpengaruh nyata. Hal ini berarti dalam pembuatan papan semen limbah batang sagu nilai kadar air papan yang dihasilkan tidak dipengaruhi oleh katalis $\mathrm{CaCl}_{2}$. Papan semen yang dihasilkan dalam penilitian ini dengan proses pengerasan lanjutan (curing) selama 2 minggu menghasilkan nilai kadar air papan semen yang hampir sama atau tidak berbeda secara signifikan antar yang satu dan yang lain.

Berdasarkan hasil perhitungan BNJ (Lampiran.2) terhadap Faktor A (posisi kulit batang sagu) yang berbeda sangat nyata, pada nilai faktor A terlihat bahwa A1terhadap A2 tidak berpengatuh nyata, sementara A1 terhadap A3 berpengaruh nyata terhadap kadar air papan. Sedangkan A2 terhadap A3 menunjukan perbedaan yang tidak nyata terhadap kadar air papan.

Hal ini berarti kadar air papan semen yang dihasilkan sangat dipengaruhi oleh posisi kulit batang sagu. Posisi kulit batang sagu bagian pangkal mempunyai kerapatan bahan yang lebih besar sehingga memiliki kadar air yang sedikit, dibandingkan pada bagian ujung yang memiliki kadar air yang lebih besar karena memiliki sel-sel kulit batang yang masih muda atau sementara mengalami pertumbuhan dengan pori-pori yang lebih besar.

Jika mengacu pada standar JIS A 5908 (2003), yang mengisyaratkan kadar air maksimal dari papan semen $16 \%$, maka seluruh papan semen yang dibuat dengan perlakuan posisi batang dan katalis $\mathrm{CaCl}_{2}$ yang berbeda memenuhi standar tersebut dimana kisaran rata-rata kadar air papan semen yang dibuat setelah proses pengkonsian selama 1 minggu masih berada dibawa batas standar dengan nilai $7,67 \%-8,02 \%$. 
Tabel 7. Analisis Sidik Ragam Kadar Air

\begin{tabular}{|c|c|c|c|c|c|c|}
\hline \multirow{2}{*}{ Sumber Keragaman } & \multirow[b]{2}{*}{ Db } & \multirow[b]{2}{*}{$\mathbf{J K}$} & \multirow[b]{2}{*}{ JKT } & \multirow{2}{*}{ F.hitung } & \multicolumn{2}{|c|}{ F. Tebel } \\
\hline & & & & & 0,01 & 0,05 \\
\hline Posisi kulit batang (A) & 2 & 0,145 & 0,0724 & $10,62 * *$ & 4,07 & 2,97 \\
\hline Katalis $\mathrm{CaCl}_{2}$ (B) & 2 & 0,0003 & 0,00015 & $0,022^{\text {tn }}$ & 4,07 & 2,97 \\
\hline $\mathrm{AB}$ & 4 & 0,001 & 0,0005 & $0,073^{\text {tn }}$ & 5,09 & 4,00 \\
\hline Galat & 18 & 0,1228 & 0,0068 & & & \\
\hline Total & 26 & 0,269 & & & & \\
\hline
\end{tabular}

Keterangan : $* *=$ sangat nyata, $\mathrm{tn}=$ tidak nyata

\section{Daya Serap Air}

Daya serap air merupakan kemampuan papan semen dalam menyerap air setelah terekspos atau terkena secara langsung ke air, ataupun direndam di dalam air. Pengujian daya serap air dalam penilitian ini dilakukan melalui metode perendaman selama 2 jam dan 24 jam. Nilai rata-rata daya serap air papan semen setelah perendaman 2 jam dalam berbagai taraf perlakuan berkisar antara 6,03\% - 7,65\% dan nilai rata-rata setelah perendaman 24 jam berkisar antara $11,62 \%-17,55 \%$. Nilai ratarata pengujian daya serap air papan semen setelah perendaman 2 jam dan 24 jam dapat dilihat pada Tabel 8 dan histogram perbedaan daya serap air papan selama perendaman 2 jam dan 24 jam pada berbagai taraf perlakuan terlihat pada Gambar 5.

Tabel 8. Rata-rata Daya Serap Air (\%) Papan Semen Pada Berbagai Taraf Perlakuan

\begin{tabular}{cc|c}
\hline Tipe papan semen & \multicolumn{2}{c}{ Rata-rata Daya Serap Air (\%) } \\
\multicolumn{2}{c}{ jam } & $\mathbf{2 4}$ jam \\
\hline A1 B1 & 7,25 & 12,51 \\
A1 B2 & 6,18 & 12,21 \\
A1 B3 & 6,03 & 11,62 \\
A2 B1 & 7,14 & 12,45 \\
A2 B2 & 7,19 & 12,56 \\
A2 B3 & 7,25 & 12,35 \\
A3 B1 & 7,33 & 12,49 \\
A3 B2 & 7,55 & 12,68 \\
A3 B3 & 7,65 & 12,91 \\
\hline
\end{tabular}

Keterangan :

A1B1 : kulit dibagian pangkal, $\mathrm{CaCl}_{2} 2 \%$

A1B2 : kulit dibagian pangkal, $\mathrm{CaCl}_{2} 4 \%$

A1B3 : kulit dibagian pangkal, $\mathrm{CaCl}_{2} 6 \%$

A3B 1 : kulit dibagian ujung, $\mathrm{CaCl}_{2} 2 \%$

A2B1 : kulit dibagian tengah, $\mathrm{CaCl}_{2} 2 \%$

A3B2 : kulit dibagian ujung, $\mathrm{CaCl}_{2} 4 \%$

A2B2 : kulit dibagian tengah, $\mathrm{CaCl}_{2} 4 \%$

A3B3 : kulit dibagian ujung, $\mathrm{CaCl}_{2} 6 \%$

A2B3 : kulit dibagian tengah, $\mathrm{CaCl}_{2} 6 \%$

Histogram pada gambar 5 menunjukan bahwa nilai daya serap air 2 jam tertinggi yaitu 7,65\% setelah perendaman 2 jam di dapat pada papan A3B3 yaitu papan yang dibuat dari kulit batang sagu pada posisi ujung dengan katalis $\mathrm{CaCl}_{2} 6 \%$, sendangkan nilai terendah yaitu $6,03 \%$ didapat pada papan A1B3 yang berasal dari kulit batang sagu pada posisi pangkal dengan menggunakan katalis $\mathrm{CaCl}_{2} 6 \%$. Selanjutnya nilai rata-rata daya serap air papan setelah perendaman 24 jam terlihat bahwa nilai tertinggi yaitu $12,91 \%$ didapat pada papan A3B3 yaitu papan yang dibuat dari kulit 
batang sagu pada posisi ujung dengan katalis $\mathrm{CaCl}_{2} 6 \%$, sedangkan nilai terendah yaitu $11,62 \%$ didapat pada papan A1B3 yaitu papan yang terbuat dari kulit batang sagu papa posisi pangkal dengan katalis $\mathrm{CaCl}_{2}$ $6 \%$.

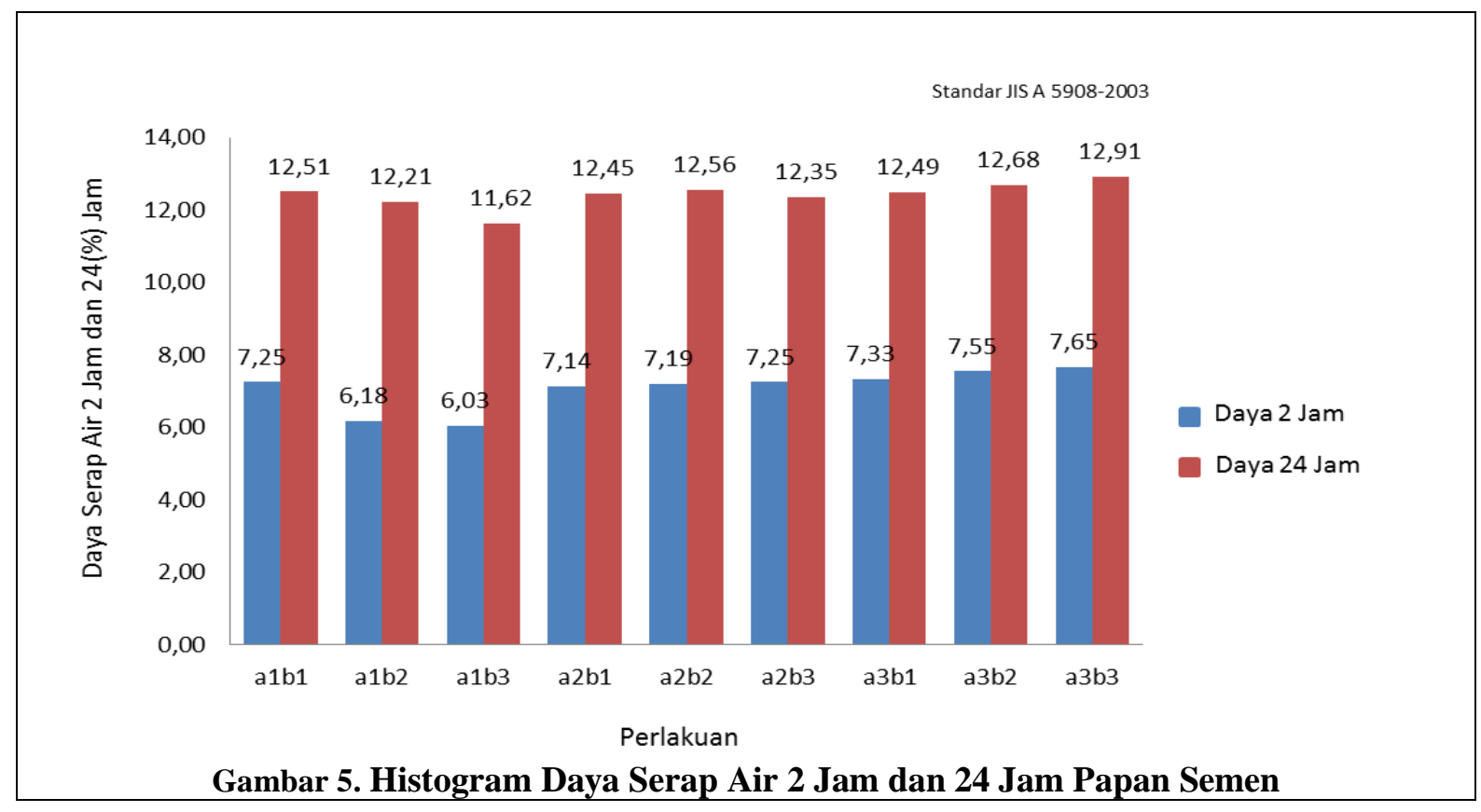

Tabel 9. Analisis Sidik Ragam Daya Serap Air 2 Jam Papan Semen

\begin{tabular}{lcccccc}
\hline Sumber keragaman & Db & JK & JKT & F.hitung & \multicolumn{2}{c}{ F. Tebel } \\
& & & & & 0,01 & 0,05 \\
\hline Posisi kulit batang (A) & 2 & 4,915 & 2,4577 & $10,29 * *$ & 4,07 & 2,97 \\
Katalis $\mathrm{CaCl}_{2}$ ( B) & 2 & 0,013 & 0,00009 & $0,004^{\text {th }}$ & 4,07 & 2,97 \\
$\mathrm{AB}$ & 4 & 0,004 & 0,001 & $0,0042^{\text {tn }}$ & 5,09 & 4,00 \\
Galat & 18 & 4,299 & 0,2388 & & \\
Total & 26 & 9,231 & & & \\
\hline
\end{tabular}

Keterangan : $* *=$ sangat nyata, $\mathrm{tn}=$ tidak nyata

Hasil analisis ragam seperti yang ditampilkan pada Tabel 9 dan 10 memperlihatkan bahwa posisi kulit batang berpengaruh nyata terhadap nilai daya serap air papan setelah perendaman 2 jam dan 24 jam pada nilai taraf 5\% dimana F-hitung perlakuan posisi kulit batang lebih besar $(10,29$ dan 7,76) dari F-tabel (4,07). Hal ini berarti daya serap air papan semen dipengaruhi oleh posisi kulit batang sagu dalam proses pembuatan papan semen tersebut.
Berdasarkan hasil perhitungan BNJ (Lampiran 3 dan 4) terhadap Faktor A (posisi kulit batang sagu) yang berbeda sangat nyata untuk daya serap air 2 jam maupun 24 jam, pada nilai faktor A terlihat bahwa A1terhadap A2 tidak berpengatuh nyata, sementara A1 terhadap A3 berpengaruh nyata terhadap daya serap air papan. Sedangkan A2 terhadap A3 menunjukan perbedaan yang tidak nyata terhadap daya serap air papan. 
Tabel 10.Analisis Sidik Ragam Daya Serap Air 24 Jam Papan Semen

\begin{tabular}{lcccccc}
\hline Sumber keragaman & Db & JK & JKT & F.hitung & \multicolumn{2}{c}{ F. Tebel } \\
& & & & & 0,01 & 0,05 \\
\hline Posisi kulit batang (A) & 2 & 1,523 & 0,76167 & $7,76^{* *}$ & 4,07 & 2,97 \\
Katalis $\mathrm{CaCl}_{2}$ (B) & 2 & 0,041 & 0,00009 & $0,001^{\text {tn }}$ & 4,07 & 2,97 \\
$\mathrm{AB}$ & 4 & 0,004 & 0,001 & $0,01^{\text {th }}$ & 5,09 & 4,00 \\
Galat & 18 & 1,767 & 0,09817 & & \\
Total & 26 & 3,336 & & &
\end{tabular}

Keterangan $: * *=$ sangat nyata, $t n=$ tidak nyata 
Kulit batang sagu pada bagian pangkal yang digunakan dalam pembuatan papan semen menyebabkan daya serap air papan semen rendah karena papan yang dihasilkan lebih kompak dengan permukaan yang lebih halus menunjukan partikel kayu terbungkus merata dengan semen dan ikatan antara partikel lebih baik, apalagi ditunjang dengan katalis yang ditambahkan dengan konsentrasi $6 \%$ menyebabkan papan semen tidak mengandung banyak pori pada permukaan papan.

Menurut Djalab (1984), pada proses pembuatan papan semen, sifat papan partikel sangat dipengaruhi oleh kondisi bahan baku (kerapatan tinggi/rendah) dan apabila semen tidak ditambahkan bahan adiktif/ katalis sebagai penahan atau penghambat air maka menyebabkan nilai daya serap air papan semen menjadi tinggi. Ditambahkan pula oleh Haygreen dan Bowyer (2003), ada beberapa bahan adiktif/katalis yang dapat ditambahkan pada papan komposit yang paling banyak digunakan adalah kalsium silicate, wax dan boraks sehingga meningkatkan resitensi ketahan terhadap air dan membuat daya serap air menjadi kecil.

Dalam penilitian ini, dirasakan juga bahwa dengan digunakan katalis $\mathrm{CaCl}_{2}$ dalam presentase 6\%, cukup berpengaruh dalam meningkatkan ketahan terhadap air karena katalis tersebut lebih memperkuat ikatan antara semen dengan partikel kulit batang sagu, sehingga papan menjadi lebih kompak disamping lebih tinggi daya penutupan terhadap permukaan partikel kulit batang sagu dan tidak mudah menyerap air serta permukaan papan menjadi lebih rata (sedikit berpori).

Didalam JIS A 5908 (2003), nilai daya serap air tidak disyaratkan. Walaupun demikian, nilai daya serap air papan semen tersebut menunjukan besarnya pertambahan berat papan akibat masuknya air setelah perendaman 2 jam dan 24 jam dibandingkan dengan berat awalnya. Mengingat penyerapan air papan semen berhubungan erat dengan stabilitas dimensi papan semen tersebut, dimana perubahan bentuk akan terjadi apabila papan mulai akan menyerap air (terutama oleh partikel kulit batang sagu), maka dihendaki jenis papan semen yang sudah tentu memiliki kemampuan menyerap air yang rendah sehingga papan tidak mudah mengembang dan stabilitas dimensi papan semen menjadi tinggi. Kondisi ini dimiliki oleh papan semen yang terbuat dari kulit batang sagu pada posisi pangkal dengan menggunakan katalis $\mathrm{CaCl}_{2}$ $6 \%$.

\section{Pengembangan tebal}

Pengembangan tebal merupakan salah satu bukti perubahan salah satu dimensi papan akibat bertambahnya ketebalan dari papan tersebut disebabkan adanya penyerapan air. Pengembangan tebal ini sangat berpengaruh terhadap stabilitas dimensi papan dan menentukan suatu papan dapat digunakan untuk keperluan eksterior atau interior (luar ruangan atau dalam ruangan).

Pengembangan tebal yang tertinggi pada papan partikel atau sejenisnya, tidak dapat digunakan untuk keperluan eksterior karena 
memiliki stabilitas dimensi produk yang rendah dan sifat mekanisnya akan rendah juga (Massijaya etal 2000 dalam Hasni, 2008). Pengujian pengembangan tebal papan semen dilakukan dengan merendam papan semen dalam air dingin selama 2 jam dan 24 jam.
Nilai rata-rata pengembangan tebal papan partikel setelah perendaman dapat dilihat pada Tabel 11, sedangkan histogram pengembangan tebal papan semen pada berbagai taraf perlakuan dapat dilihat pada Gambar 6 .

Tabel 11. Rata-rata Pengembangan Tebal Papan (\%) Pada Berbagai Taraf Perlakuan

\begin{tabular}{cc|c}
\hline Tipe Papan Semen & $\begin{array}{c}\text { Rata-rata Pengembangan Tebal (\%) } \\
\text { 2 jam }\end{array}$ \\
\hline A1 B1 & 1,78 & 1,92 \\
A1 B2 & 1,73 & 1,91 \\
A1 B3 & 1,64 & 1,90 \\
A2 B1 & 1,80 & 1,94 \\
A2 B2 & 1,78 & 1,95 \\
A2 B3 & 1,79 & 1,97 \\
A3 B1 & 1,82 & 1,97 \\
A3 B2 & 1,81 & 2,10 \\
A3 B3 & 1,80 & 2,14 \\
\hline
\end{tabular}

Keterangan :

A1B1 : kulit dibagian pangkal, $\mathrm{CaCl}_{2} 2 \%$

A1B2 : kulit dibagian pangkal, $\mathrm{CaCl}_{2} 4 \%$

A1B3 : kulit dibagian pangkal, $\mathrm{CaCl}_{2} 6 \%$

A2B1 : kulit dibagian tengah, $\mathrm{CaCl}_{2} 2 \%$

A2B2 : kulit dibagian tengah, $\mathrm{CaCl}_{2} 4 \%$

Hasil yang tergambar dalamTabel 12 memperlihatkan bahwa nilai pengembangan tebal 2 jam tertinggi yaitu $1,82 \%$ terdapat pada papan semen A3B1 yakni papan semen yang terbuat dari kulit batang sagu pada posisi ujung dengan katalis $2 \%$, sedangkan nilai terendah yaitu $1,64 \%$ terdapat pada papan semen A1B3 yaitu papan semen yang terbuat dari kulit batang sagu pada posisi pangkal dengan katalis $\mathrm{CaCl}_{2} 6 \%$.
A2B3 : kulit dibagian tengah, $\mathrm{CaCl}_{2} 6 \%$ A3B1 : kulit dibagian ujung, $\mathrm{CaCl}_{2} 2 \%$ A3B2 : kulit dibagian ujung, $\mathrm{CaCl}_{2} 4 \%$ A3B3 : kulit dibagian ujung, $\mathrm{CaCl}_{2} 6 \%$

Tabel 12. Analisis Sidik Ragam Pengembangan Tebal 2 jam

\begin{tabular}{lcccccc}
\hline Sumber keragaman & Db & JK & JKT & F.hitung & \multicolumn{2}{c}{ F. Tebel } \\
& & & & & 0,01 & 0,05 \\
\hline Posisi kulit batang (A) & 2 & 0,047 & 0,02349 & $10,53 * *$ & 4,07 & 2,97 \\
Katalis $\mathrm{CaCl}_{2}$ (B) & 2 & 0,000 & 0,000085 & 0,038 & 4,07 & 2,97 \\
$\mathrm{AB}$ & 4 & 0,004 & 0,001 & 0,448 & 5,09 & 4,00 \\
Galat & 18 & 0,040 & 0,00223 & & \\
Total & 26 & 0,092 & & & \\
\hline Keterangan : **: berbeda nyata; tn : tidak nyata $;$ n: nyata
\end{tabular}

Sementara pada perendaman 24 jam nilai tertinggi yaitu $2,14 \%$ terdapat pada papan semen A3B3 yaitu papan semen yang terbuat dari kulit batang sagu pada posisi ujung dengan katalis $\mathrm{CaCl}_{2} 6 \%$, dan nilai terendah yaitu $1,90 \%$ terdapat pada papan semen A1B3 yaitu papan semen yang terbuat dari kulit batang sagu pada posisi pangkal dengan katalis $\mathrm{CaCl}_{2} 6 \%$. 
Tabel 13. Analisis Sidik Ragam Pengembangan Tebal 24 Jam

\begin{tabular}{lcccccc}
\hline Sumber keragaman & Db & JK & JKT & F.hitung & \multicolumn{2}{c}{ F. Tebel } \\
& & & & & 0,01 & 0,05 \\
\hline Posisi kulit batang (A) & 2 & 0,122 & 0,06121 & $16,979^{* *}$ & 4,07 & 2,97 \\
Katalis $\mathrm{CaCl}_{2}(\mathrm{~B})$ & 2 & 0,001 & 0,000085 & 0,023 & 4,07 & 2,97 \\
$\mathrm{AB}$ & 4 & 0,004 & 0,001 & 0,027 & 5,09 & 4,00 \\
Galat & 18 & 0,065 & 0,00360 & & \\
Total & 26 & 0,192 & & & \\
\hline
\end{tabular}

Keterangan: **: berbeda nyata; th : tidak nyata ; $n:$ nyata

Hasil analisis sidik ragam pada pengembangan tebal 2 jam dan 24 jam menunjukan bahwa posisi kulit batang sagu dan presentasi katalis $\mathrm{CaCl}_{2}$ yang digunakan berpengaruh nyata terhadap nilai pengembangan terbal papan,dimana F-hitung taraf (5\%) lebih besar dari F-tabel (5\%). Hal ini berarti pengembangan tebal papan semen di pengaruhi oleh posisi kulit batang sagu dan presentase katalis $\mathrm{CaCl}_{2}$ yang digunakan.

Berdasarkan hasil perhitungan BNJ (Lampiran 5 dan 6) terhadap Faktor A (posisi kulit batang sagu) yang berbeda sangat nyata untuk pengembangan tebal setelah perendaman 2 jam maupun 24 jam, pada nilai faktor A terlihat bahwa A1terhadap A2 tidak berpengatuh nyata, sementara A1 terhadap A3 berpengaruh nyata terhadap pengembangan tebal papan. Sedangkan A2 terhadap A3 menunjukan perbedaan yang tidak nyata terhadap pengembangan tebal papan.

Kulit batang sagu pada bagian pangkal yang digunakan dalam pembuatan papan semen menyebabkan daya serap air papan semen rendah dan berkorelasi dengan pengembangan tebal yang rendah pula, dikarenakan papan yang dihasilkan lebih kompak dengan permukaan yang lebih halus karena partikel kayu terbungkus merata dengan semen dan ikatan antara partikel lebih baik, apalagi ditunjang dengan katalis yang ditambahkan dengan konsentrasi 6\% menyebabkan papan semen tidak mengandung banyak pori pada permukaan papan.

Setiawati (2000), menyatakan bahwa pengembangan tebal diduga ada hubungan dengan absorbsi air, karena semakin banyak air yang diabsorbsi dan memasuki struktur partikel kayu atau bahan lignoselulosa lainnya, maka semakin banyak pula penambahan dimensi yang dihasilkan. Hal tersebut dibuktikan dengan adanya pengembangan tebal pada papan walaupun nilainya tidak terlalu tinggi.

Dalam JIS A 5908 (2003), nilai pengembangan tebal yang diisyaratkan bagi papan yang berukuran tebal $12 \mathrm{~mm}$ adalah kurang lebih $1 \mathrm{~mm}$ atau sebesar $8,3 \%$ dan bila dibandingkan dengan hasil penelitian menunjukan bahwa papan semen yang dibuat dengan waktu pengerasan 2 minggu sudah memenuhi batas toleransi pengembangan tebal papan semen yang diisyaratkan. Papan semen yang dibuat dalam penilitian seluruhnya memenuhi batas standar pengembangan tebal papan yang disyaratkan JIS A 5908 (2003). 


\section{KESIMPULAN DAN SARAN}

1. Kulit batang sagu pada berbagai posisi ketinggian (pangkal, tengah dan ujung) dapat dimanfaatkan dalm proses pembuatan papan semen dimana papan yang terbuat dari kulit batang bagian pangkal dengan katalis $\mathrm{CaCl}_{2} 6 \%$ memiliki sifat fisik yang baik dan memenuhi standar JIS A 5908 (2003).

2. Kerapatan papan semen berkisar antara $1,19-1,26 \mathrm{gr} / \mathrm{cm}^{3}$. Nilai kerapatan papan semen tertinggi 1,26 $\mathrm{gr} / \mathrm{cm}^{3}$ terdapat pada papan yang terbuat dari kulit batang sagu pada posisi pangkal dengan katalis $\mathrm{CaCl}_{2}$ 6\% (A1B3), sedangkan nilai kerapatan terendah yaitu $1,19 \mathrm{gr} / \mathrm{cm}^{3}$ terdapat pada papan yang terbuat dari kulit batang sagu pada posisi ujung dengan katalis $\mathrm{CaCl}_{2} 2 \%$ (A3B1). Posisi kulit batang sagu berpenggaruh nyata terhadap kerapatan papan.

3. Kadar air papan semen berkisar antara $7,67 \%-8,02 \%$. Kadar air tertinggi yaitu papan semen $8,02 \%$ terdapat pada papan semen terbuat dari kulit batang sagu pada posisi ujung dengan katalis $2 \%$, sedangkan nilai terendah yaitu $7,67 \%$ pada papan semen yang terbuat dari kulit batang sagu pada posisi pangkal dengan katalis $6 \%$.
Kadar air papan semen dipengaruhi oleh posisi kulit batang sagu.

4. Rata-rata daya serap air papan semen berkisar setelah perendaman 2 jam berkisar antara $6,03-7,65 \%$ dan sedangkan setelah perendaman 24 jam berkisar antara $11,62 \% \quad-12,91 \%$. Pengembangan tebal papan semen setelah perendaman 2 jam rata-rata berkisar pada $1,62-12,91 \%$, sedangkan setelah perendaman 24 jam berkisar antara $1,40 \%-3,41 \%$. Daya serap air dan pengembangan tebal dipengaruhi oleh posisi bahan baku yaitu kulit batang sagu pada bagian pangkal dan ditunjang dengan penambahan katalis

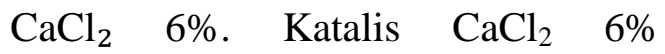
menghasilkan papan dengan stabilitas dimensi yang tinggi dengan nilai daya serap air dan pengembangan tebal yang rendah.

5. Produk papan semen yang terbuat dari kulit batang sagu dan katalis $\mathrm{CaCl}_{2}$ dalam penilitaian ini memenuhi standar JIS A 5908 (2003). 


\section{DAFTAR PUSTAKA}

Bison, 1975. Cement-Bonded Particleboard Plant Integrated With Low Cost Housing Production Unit Case Study Prepared for FAO, Portofolio of Scale Forest Industries for Developing Countries. Bison Werhe Bahre and Breten Bmtt and Co. 3257 Spring IFR. Germany.

Brown, HP., Panshin, AJ., and Forsaith, CC., 1952. Text Book of Wood Technology, Vol.II, McGraw-Hill Book Company, Inc., New York.

Coutts, RSP., 2000. Natural Fiber-cement Composite : An Australian Prespectives." Proceeding WoodCement Composite in the Asia-Pacific Region. hlm. 131-139. Australian Centre for International Agricultural Research (ACIAR). 10 Desem ber 2000. Rydges Hotel, Canberra, Australia.

Djumadi, A., 1989. Sistem Pertanian Sagu di Daerah Luwu Sulsel. Thesis Pasca Sarjana IPB. Bogor.

Fernandes, EC., CRG., Lamason, TS. Delgado, 2000(a). Cement- Bonded Board From Wastewater treatment sludge of a recycled paper Mill. Proceeding Wood-Cement Composite in the Asia-Pacific Region. hlm. 7380. Australian Centre for Inter national Agricultural Research (ACIAR). 10 Desember 2000. Rydges Hotel, Canberra, Australia.

Fernandes, EC., VP. Tajaon, 2000(b). The use and processing of rice straw in the manufacture of cement-bonded fiberboard. Proceeding Wood-Cement Composite in the Asia-Pacific Region. hlm. 49-54. Australian Centre for International Agricul- tural Research (ACIAR). 10 Desember 2000. Rydges Hotel, Canberra, Australia.

Flach, M., 1983. Yield Potential of the sago palm (Metroxyloan sagu) and its realisation. Proc . Sago Conference in Serawak. Malaysia .

Harsanto, P.B., 1986. Budidaya dan Pengolahan Sagu. Kanisius. Yogyakarta.

Haryanto, B. dan Pangloli, P.1992. Potensi dan Pemanfaatan Sagu. Kanisius, Bogor.

Haygreen dan Bowyer, 1989. Hasil Hutan dan Ilmu Kayu. Suatu Pengantar. Gadjah Mada University Press, Yohyakarta.

Hermawan, D., 2001. Manufacture of Cement-Bonded Particleboard Using Carbon Dioxide Curing Technology. Disertation Presented to the Departement of Forest and Biomass Science. Graduate School of the Faculty of Agriculture. Kyoto University.

Japanese Standards Association. 1994. Japanese Industrial Standard (JIS) Particle Board. No. 5908-1994.

Jose \& A. Rasyad, 1997. Sago : the future source of food and feed. Riau University. Training Center, Pekanbaru. p.225-30.

Kamil, R. N., 1970. Prospek Pendirian Industri Papan Wol Kayu di Indonesia, Pengumuman No. 95. LPHH. Bogor.

Louhenapessy, JE., 1998. Sagu di Maluku (Harapan dan Tantangan dalam Pembangunan), Disampaikan dalam Seminar Berkala pada Pusat Studi Maluku, Unpatti, Ambon.

Maail, R.S., 2011. Curing and Degradation Processes of Cement Bonded Particleboad by Supercritical CO2 Treatment, J. Wood Sci (2011) 57:302-307.

Maloney, TM. 1977. Modern Particle Board an dry Proces Fiberboard Manufacturing. San Fransisco: Miller Freeman Inc.

Masri, S., 1998. Pengaruh Panjang Sabut, Katalisator dan Kadar Semen Terhadap Sifat Papan Semen Sabut Kelapa (Cocos nucifera L.). Skripsi. Fakultas Kehutanan IPB, Bogor.

Meulenhoff, M. dan Tambunan, B., 1980. Perencanaan Industri Panil - Panil Kayu dalam Rangka Pemanfaatan Limbah. Diskusi Industri Perkayuan. Maret 26-27. Jakarta.

Miller, D.P. and A.A. Moslemi, 1991. Wood Cement Composite: Species and Heartwood-Sapwood Effect on 
Hydration and Tensile Strength. Forest Products Journal, Volume 41 No.3. Forest Products Research Society, Madison, WI, USA.

Moslemi, A.A., 1994. Inorganic Bonded Wood and Fiber Composite : Technologies and Application Second Pasific Rim Bio Based Composite Symposium. November 6-9. Vancouver. Canada.

Moslemi, A.A; I.F. Garcia and A.D. Hotstrand, 1983. Effect of Various Treatment and Additives on Wood Portland Cement - Water System. Wood and Fiber Science 15 (2). PP $164-176$

Mulyono, T., 2003. Teknologi Beton. Departemen Pendidikan Nasional. Direktorat Jendral Pendidikan Tinggi. Jakarta.

Pease, D.A., 1994. Panel : Product, Applications and Production Trends, Miller Freeman, USA.

Purnomo, E., 1988. Pengaruh Perlakuan Awal, Katalisator dan Kadar Semen Terhadap Sifat Papan Semen Sabut Kelapa. Skripsi. Fakultas Kehutanan IPB. Bogor.

Purwoko, T. dan Bedjo, 1980. Petunjuk Praktek Batu dan Beton Jilid 1 . Depatemen Pendidikan dan Kebudayaan. Direktorat Pendidikan Menengah dan Kejuruan.

Riyanto, 2003. Pengaruh Pemberian Accelerators $\mathrm{CaCl}_{2}$ dan $\mathrm{Na}_{2} \mathrm{SO}_{4}$ Terhadap Sifat Fisis Mekanis Papan Semen Partikel. Skripsi. Fakultas Kehutanan IPB. Bogor. Tidak Diterbitkan.

Rumalatu, FJ., 1981. Distribusi dan Potensi Pati Beberapa Sagu (Metroxylon, sp) di Daerah Seram Barat. Karya Ilmiah, Fakultas Pertanian/Kehutanan yang Berafiliasi dengan Fateta IPB. Bogor.

Semple, K.E., and P.D., Evans, 2000. Screening Inorganic Additives for Ameliorating the Inhibition of Hydration of Portland Cement by the Heratwood of Acacia mangium in Wood-Cement Composites in the Asia-Pacific Region. Proceeding of a Workshop Held at Rydges Hotel, Canberra Australia, 10 Desember
2000.

Setiawati, W., 2000. Pengaruh Perendaman Partikel, Macam Katalis dan Kadar Katalis terhadap Sifat Papan Semen Partikel Bambu Betung (Dendrocalamus asper Backer). Skripsi. Fakultas Kehutanan IPB. Bogor. Tidak Diterbitkan.

Simatupang, 1974. Pembuatan dan Penggunaan Campuran Semen dan Kayu Sebagai Bahan Bangunan, Kehutanan Indonesia 390-392.

Soekarto, S.T., dan S. Wijandi, 1983. Prospek pengembangan sagu sebagai sumber pangan di Indonesia. Biro Koordinasi dan Kebijaksanaan Ilmiah, LIPI . Jakarta.

Subianto, B., 1998. The Effect of Cement after Pre-Treatment of Particle on Cement Bonded Particleboard Properties. Production Technology of Cement Bonded Particleboard from Tropical Fast Growing Species I. Di dalam : Hadi YS, editor. Proceedings The Fourth Rim Bio-Based Composites Symposium, Bogor, 2-5 November 1998.

Sutigno, et.al., 1977. Sifat Papan Semen Lima Jenis Kayu. Laporan (Report) No. 96. Lembaga Penelitian Hasil Hutan. Bogor.

Sutigno, P., 1979. Catatan Mengenai Beberapa Industri Kayu di Sumatera. Laporan No.135. Lembaga Penelitian Hasil Hutan. Badan Penelitian dan Pengem-bangan Pertanian. Departemen Pertanian. Bogor.

Tenda, E.T, H.F. Mangindaan dan J. Kumaunang. Eksplorasi Jenis-Jenis Sagu Potensial di Sulawesi Tenggara. Makalah Poster Pada Seminar Nasional. 
